\title{
Pelatihan Kreatifitas Pembuatan Alat Permainan Edukatif Bagi Orang Tua Siswa PAUD
}

\author{
Ni Made Sulastri \& Dewi Rayani \\ Dosen Fakultas Ilmu Pendidikan dan Psikologi \\ Universitas Pendidikan Mandalika \\ nimadesulastri@,ikipmataram.ac.id
}

\begin{abstract}
The purpose of this community service activity is to increase the creativity of making educational game tools for parents of students' parents. This is based on several observations and found indications that most parents do not use their time well when activities wait for children to go home from school, parents only spend time without meaningful activities they usually spend just by chatting with other parents, sometimes teachers also accompany their children to learn in the classroom where these activities greatly interfere with the ongoing teaching and learning process. As a result of the routine and busyness of the parents, it is necessary to have activities that can be useful for parents and also for children's growth and development. Because in supporting the growth and development of children, educational tools are also needed that can be made by the teacher or parents themselves, so it is necessary to provide a creative training to develop educational games for parents. The method used in community service activities is in the form of counseling / education. Involved parents as much as 20. Community service activities include the provision of material on how to develop creativity to make educational games.
\end{abstract}

Abstrak; Tujuan dari kegiatan pengabdian pada masyarakat ini adalah untuk meningkatkan kreatifitas pembuatan alat permainan edukatif bagi orang tua siswa orang tua siswa. Hal ini didasarkan beberapa pengamatan dan menemukan indikasi bahwa kebanyakan orang tua siswa tidak memanfaatkan waktu dengan baik pada saat aktifitas menunggu anak-anak sampai jam pulang sekolah, orang tua hanya menghabiskan waktu tanpa kegiatan yang bermakna biasanya mereka habiskan hanya dengan mengobrol dengan orang tua lainnya, terkadang juga guru ikut menemani anak-anak mereka belajar di dalam kelas diman aktifitas tersebut sangat menggangu proses belajar mengajar yang sedang berlangsung. Akibat dari rutinitas dan kesibukan orang tua tersebut diperlukan adanya kegiatan yang dapat berguna untuk orang tua dan juga terhadap pertumbuhan dan perkembangan anak. Kareana dalam mendukung tumbuh dan kembang anak diperlukan pula alat permainan edukatif yang dapat dibuat sendiri oleh guru ataupun orang tua, sehingga dirasa perlu untuk memberikan suatu pelatihan kreatifitas untuk mengembangkan alat permainan edukatif bagi orang tua. Metode yang digunakan dalam kegiatan pengabdian pada masyarakat ini adalah dalam bentuk penyuluhan/edukasi. Orang tua yang terlibat sebanyak 20 orang. Kegiatan pengabdian pada masyarakat ini meliputi pemberian materi mengenai cara mengembangakan kreatifitas untuk membuat alat permainan edukatif.

Kata Kunci : Kreativitas, Alat Permainan Edukatif.

\section{PENDAHULUAN}

Adapun gambaran situasi lokasi pengabdian pada masyarakat adalah PAUD alang-alang adalah PAUD yang berada di daerah tanjung karang, loang balok. Keadaan PAUD masih sangat sederhana, kebanyakan siswa-siswi PAUD adalah warga desa setempat dan orang tua siswa berperofesi sebagai ibu rumah tangga biasa. Kebanyakan dari wali siswa (ibu-ibu) mengatar dan bahkan menunggu siswa hingga pulang sekolah. Aktifitas ibu-ibupun beragam ketika menunggu siswa di PAUD, namun kebanyakn dari ibu-ibu tersebut menghabiskan waktu hanya dengan mengobrol dan berbagi cerita antara ibu yang satu dengan yang lainnya. Gambaran aktifitas ini terlihat sia-sia. Dengan keadaan ini maka tim pengabdi akan memberikan sebuah pelatihan bagi orang tua siswa guna dapat memanfaatkan waktu luang. Adapun jenis pelatihan berupa pembuatan alat permainan edukatif sederhana, gampang dan 
menyenangkan. Alat permainan ini diharapkan bias mengembangkan kreatifitas orang tua dan hasilnya dapat digunakan oleh siswa-siswi PAUD ketika berada di rumah.

Kreatifitas merupakan kemampuan seseorang untuk melahirkan sesuatu yang baru, baik berupa gagasan maupun karya nyata, yang relative berbeda dengan apa yang telah ada sebelumnya. Menurut Moreno dalam Slameto yang penting dalam kreativitas itu bukanlah penemuan sesuatu yang belum pernah diketahui orang sebelumnya, melainkan bahwa produk kreativitas itu merupakan sesuatu yang baru bagi diri sendiri dan tidak harus merupakan sesuatu yang baru bagi orang lain atau dunia pada umumnya.

Kretifitas dalam memahami alat permaian edukatif yang sesuai dengan perkembangan anak usia dini sangat diperlukan, alat permaian edukatif merupakan media yang dapat membantu guru dan orang tua dalam pembelajaran anak usia dini, serta membantu pertumbuhan dan perkembangan anak agar tumbuh dengan baik. Dalam pendidikan anak usia dini kreatifitas umumnya harus dimiliki oleh seorang guru, tetapi untuk mendukung keberhasilan pendidikan anak usia dini.

Peran pendidikan bukan hanya tanggung jawab guru di sekolah, peran orang tua sebagai pendidik adalah yang utama. Sehingga diperlukan kreatifitas bagi orang tua siswa untuk dapat membuat alat permainan edukatif untuk membantu aktifitas pembelajaran anak usia dini. Namun masih banyak orang tua siswa yang kurang memiliki kreatifitas dalam membuat alat permainan edukatif untuk anak-anaknya. Lebih banyak waktu yang tidak dimanfaatkan dengan baik, pada orang tua siswa di paud alang-alang kebanyakan orang tua siswa di dalam aktifitas mengantar dan sampai menunggu anaknya di sekolah tidak memanfaatkan waktu dengan efektif. Banyak orang tua hanya menunggu saja sambil bercerita dengan ibu-ibu lainya. Dengan harapan kedepannya orang tua dapat menunggu anak-anak yang akan pulang sekolah dapat memanfaatkan waktu dengan baik dengan cara mengembangkan kreatifitasnya.
Dari latar belakang di atas maka kami bermaksud untuk memberikan pelatihan kretifitas dan pembuatan alat permainan edukatif bagi orang tua siswa di paud alangalang.

\section{STRATEGI DAN TARGET LUARAN}

Target dan luaran yang diharapkan dari kegiatan Pengabdian pada Masyarakat ini, khususnya bagi orang tua murid yang memiliki anak di Paud Alang-alang adalah:

1. Peningkatan Kreatifitas orang tua dalam membuat alat permaian edukatif.

2. Para orang tua murid dapat memahami dan mengenal fungsi berbagai alat permaianan edukatif untuk menunjang proses belajar mengajar pada anak, serta membantu pertumbuhan dan perkembangan pada anak.

\section{METODE PELAKSANAAN}

Metode dalam pelaksanaan program pengabdian pada masyarakat ini adalah dalam bentuk penyuluhan/edukasi menggunakan sistem demonstrasi dan praktik langsung dalam menyampaikan materi pelatihan untuk memperlancar pelaksanaan kegiatan tersebut. Dengan metode demonstrasi dan praktik langsung diharapkan terjalis diskusi terbuka secara langsung kepada orang tua siswa sehingga menciptakan suasana pelatihan yang menyenangkan, kreatif, dan bermakna, serta dapat bermanfaat dan menyenangkan diskusi terbuka dengan orang tua murid dan berbagai pengalaman dalam mengemabangkan kreatifitas dan pembuatan alat permainan edukatif.

Persiapan kegiatan pelatihan ini dimulai dengan melakukan koordinasi dengan Tim PPM antara dosen dengan mahasiswa untuk menyiapkan berbagai kebutuhan dan mekanisme kegiatan pelatihan yang akan diselenggarakan. Selanjutnya tim PPM melakukan koordinasi dengan pengelola (pimpinan, staf dan tutor) PAUD alang-alang, dalam rangka menyamakan persepsi terkait dengan teknis pelaksanaan kegiatan. Koordinasi dilakukan dengan melakukan pertemuan di lokasi PAUD alang-alang sekaligus mengadakan diskusi dan observasi terkait dengan tempat pelaksanaan kegiatan penyuluhan/edukasi. Selanjutnya tim PPM mengembangkan berbagai materi yang akan 
disampaikan yang dapat menjadi pedoman bagi peserta selama mengikuti kegiatan pelatihan.

\section{HASIL KEGIATAN}

Pelaksanaan kegiatan pelatihan kreatifitas bagi orang tua siswa di Paud Alang-alang, bertempat di PAUD AlangAlang. Peserta yang mengikuti proses pelatihan berjumlah 20 orang tua siswa yang memiliki putra putri yang bersekolah di Paud tersebut.

Respon dari peserta terkait dengan kegiatan pelatihan ini sangat positif dan mendukung dengan baik, hal ini terindikasi dari peserta pelatihan yang aktif (partisipatif) dalam mengikuti dan merespon proses kegiatan Selain itu, peserta pelatihan yang merupakan wali murid PAUD Alang-alang mimiliki antusias selama proses penyampaian materi pelatihan. Selama proses pelatihan, kemampuan kreatifitas orang tua siswa juga sudah mulai nampak, terlihat ketika proses kegiatan berlangsung para orang tua siswa dapat menbuat berbagai alat permainan edukatif setelah mendapat penjelasan materi dari para Tim Pengabdian.

Materi-materi yang disampaiakan oleh Tim PKM merupakan materi-materi yang telah disusun untuk mengembangkan kreatifitas dalam mengolah barang bekas menjadi benda-benda yang lebih bermanfaat. Salah satu benda yang dibuat dalam kegiatan pengabdian ini adalah alat permaian edukatif yang dapt digunakan dalam kegiatan belajar mengajar pada anak, alat permaian edukatif ini berfungsi untuk mengenalkan angka, huruf, bentuk, dan berbagai macam warna. Selain itu juga dapat merangsang kemampuan motorik anak dari kegiatan memasang dan menempel berbagai bentuk yang telah dibuat. Sehingga tujuan dari kegiatan ini untuk dapat memberikan ruang dan kesempatan bagi peserta pelatihan dalam mengembangkan kreatifitas memanfaatkan barang bekas menjadi benda yang lebih bermanfaat serta memiliki pengetahuan tentang cara memeberikan penglaman belajar yang baik dengan kreativitas alat permainan yang telah dibuat.

Setelah kegiatan pengabdian pada masyarakat ini dilaksanakan selama satu hari dalam kegiatan pelatihan yang berkaitan dengan pemberdayaan masyarakat di PAUD Alang-alang, Hasil Pengabdian ini kami selaku pelaksana pengabdian melakukan wawancara dengan guru dan orang tua dan mendapat masukan agar kegiatan pelatihan ini dapat terus dilaksanakan. Agar orang tua semakin paham tentang pemanfaatan barang bekas, serta memiliki pengetahuan tentang cara mengembangkan kemampuan anak dengan berbagai alat permainan edukatif yang dapat dibuat sendiri. Berdasarkan pembicaraan dan kesepakatan para tutor paud dan masyarakat, pada kesempatan lain akan ditindaklanjuti dengan pembimbingan dan pendampingan secara periodik. Selama kegiatan pelatihan berlangsung, Tim PPM juga berupaya untuk melakukan monitoring terkait dengan proses pelatihan untuk mengetahui secara jelas kelemahan atau kekurangan yang ada. Monitoring ini juga merupakan salah satu bentuk dari penjaminan mutu kegiatan pelatihan dan sebagai upaya memberikan manfaat bagi peserta pelatihan terhadap kegiatan yang telah dilakasanakan.

Khusus untuk sesi diskusi (tanya Jawab), banyak peserta pelatihan yang mengajukan pertanyaan penting terhadap penyampaian materi yang bersifat praktik. Peserta pelatihan terlihat antusias ketika tim PKM menyampaikan berbagai materi yang berkaitan dengan pelatihan kreativitas pemanfaatan barang bekas menjadi alat permaianan edukatif ini.

\section{Evaluasi Kegiatan}

Setelah penyampaian materi dan pelaksanaan kegiatan penyuluhan pendidikan, Tim PPM berupaya untuk melakukan evaluasi terhadap implementasi dari pelatihan yang diselenggarakan. Evaluasi ini bertujuan untuk mengetahui tingkat keberhasilan dari pelaksanaan kegiatan pelatihan yang dilakukan.

a. Evaluasi Proses

Evaluasi proses ini berupaya untuk mengetahui tingkat partisipasi, respon, dan pemahaman terhadap materi pelatihan yang disampaikan kepada peserta. Dari sisi partisipasi, yang ditargetkan mengikuti pelatihan ini adalah seluruh wali murid PAUD Alang-alang. Dalam kenyataannya, 
hampir semua peserta hadir dan ikut berpartisipasi aktif selama kegiatan pelatihan berlangsung. Kemudian, respon peserta terhadap kegiatan pelatihan ini menunjukkan dukungan yang positif dan memandang perlu untuk mengembangkan kegiatan sejenis yang dapat berkenjutan.

b. Evaluasi Hasil (Produk)

Pada aspek evaluasi hasil (produk) pelatihan ini, Tim PPM berupaya untuk malakukan evaluasi terkait dengan tingkat pemahaman peserta pelatihan. Terkait dengan evaluasi hasil kegiatan pelatihan ini, Tim PPM berupaya melakukan observasi (pengamatan) secara cermat terhadap antusime peserta dalam hal ini para orang tua murid di PAUD Alang-alang. Berdasarkan hasil pengamatan didapatkan bahwa antusias peserta sangat tinggi terhadap kegiatan pelatihan tersebut.

Mengacu pada indikator keberhasilan kegiatan pelatihan ini, secara umum pelaksanaan kegiatan pelatihan pendidikan bagi wali murid tentang pelatihan kreatifitas pemanfaatan barang bekas menjadi alat permainan edukatif ini telah mencapai indikator keberhasilan yang telah ditentukan. Indikator keberhasilan dari pelaksanaan kegiatan pelatihan ini antara lain:

1. Peserta pelatihan aktif (partisipatif) dan bekerjasama dengan baik selama mengikuti kegiatan, hal ini dapat terlihat dari tingkat kehadiran peserta, aktivitas diskusi dan tanya jawab antara peserta dan pemateri yang dialogis. Selain itu, peserta pelatihan kooperatif untuk dapat mendukung keterlaksanaan kegiatan pelatihan ini.

2. Peserta pelatihan memahami materimateri pelatihan, hal ini dapat diukur dari pencapaian kemampuan memahami materi-materi pelatihan, dan prodak alat permainan edukatif.

\section{Rencana Tindak Lanjut}

Kegiatan pengabdian pada masyarakat (PPM) melalui pelatihan pemanfaatan barang bekas bagi wali murid ini tidak dilakukan secara parsial, artinya setelah selesai kegiatan, selesai pula seluruh aktivitasnya. Akan tetapi, pasca kegiatan pelatihan ini, Tim PPM akan terus berupaya untuk menindaklanjuti kegiatan yang telah dilaksanakan dengan mengidentifikasi kekurangan atau kelemahan Oleh karena itu, bentuk tindak lanjut yang akan dilakukan adalah dilaksanakannya kegiatan serupa dalam rangka memenuhi antusias wali murid tentang kreatifitas mengolah barang bekas menjadi benda yang lebih bermanfaat atau alat permaianan edukatif bagi pertumbuhan dan perkembangan anak.

\section{SIMPULAN}

Pelatihan tentang kreativitas pembuatan alat permaianan edukatif bagi orang tua siswa Paud ini, memberikan dampak yang positif bagi pihak sekolah, orang tua, dan masyarakat. Sehingga kedepannya perlu adanya kegiatan serupa terutama bagi wali murid dalam mendalam kreativitas membuat alat permainan edukatif yang berguna bagi pemebelajaran, serta pertumbuhan dan perkembangan anak.

\section{SARAN}

Setelah adanya kegiatan Pelatihan tentang kreativitas pembuatan alat permaianan edukatif bagi orang tua siswa Paud ini, mampu menjadi mitra dalam mengembangkan kreativitas orang tua dan memanjukan lembaga sekolah.

\section{DAFTAR PUSTAKA}

Hadimiarso, Yusuf. 2005. Menyemai Benih Teknologi Pembelajaran. Jakarta:Pustekkom Depdiknas.

Moeslichatoen R, Metode Pengajaran di TK, Jakarta: Rineka Cipta, 2004.

Munandar, S.C. Utami, Mengembangkan Bakat dan Kreativitas Anak Sekolah, Jakarta: PT. Grasindo, 1999.

Rachmawati Yeni, Euis Kurniati, Strategi Pengembangan Kreativitas Pada Anak Usia Taman Kanak-Kanak, Jakarta: Depdiknas, 2005.

Hadimiarso, Yusuf. 2005. Menyemai Benih Teknologi Pembelajaran. Jakarta:Pustekkom Depdiknas. 